Ömer Halisdemir Üniversitesi Îktisadi ve İdari Bilimler Fakültesi Dergisi

Yll: 2021 Cilt-Sayı: 14(3) ss: $948-960$

Academic Review of Economics and Administrative Sciences

Year: 2021 Vol-Issue: 14(3) pp: 948-960

https://dergipark.org.tr/tr/pub/ohuiibf/

ISSN: 2564-6931

DOI: 10.25287/ohuiibf.795657

Arașturma Makalesi

Geliş Tarihi / Received: 16.09.2020

Research Article

\title{
A STUdy On CONFIDENCE INDEXES In TURKey UNDER Structural Breaks For The Period Covering The Covid-19 Pandemic
}

Esra N. KILCI ${ }^{I}$

\begin{abstract}
The most important feature of confidence indicators is probably the information they provide about the major determinants of consumption, production, and investment decisions. As they indicate future patterns of consumption, production, and investments, many economic agents including households, businesses, and central banks integrate these indicators into their processes of forecasting and decision-making. In this context, confidence indexes, which are used basically to assess the expectations of households and businesses regarding the economic outlook, have the power to reflect the changes in macroeconomic fundamentals. The key objective of this paper is to analyze the trend of confidence indexes for Turkey from 2012:05 through 2020:09. In this study, we employ the Carrion-i Silvestre et al. (2009) unit root test which accounts for multiple structural breaks to test the stationary of the consumer, financial services, and real sector confidence indexes. We find that the financial and real sector confidence indexes have a stable trend, while the consumer confidence index does not have a consistent pattern in the relevant period. Our analysis also provides information regarding the dates of structural breaks.
\end{abstract}

Keywords : Confidence indicators, Uncertainty, Structural breaks.

Jel Classification : C10, E70, G40.

\footnotetext{
${ }^{1}$ Doç. Dr., İstanbul Üniversitesi-Cerrahpaşa, Sağlık Bilimleri Fakültesi, Sağlık Ekonomisi Ana Bilim Dalı, esra.kilci@iuc.edu.tr,
} ORCID: 0000-0002-2239-4560. 


\title{
YAPISAl Kirilmalar DiKKate AlinaraK TÜRKIYYe'de Covid-19 Pandemísini KAPSAYAN Dönemde GÜVEN ENDEKSLERi ÜZERINe YAPILAN Bír ÇALIŞMA
}

\begin{abstract}
$\ddot{O} z$
Güven indikatörlerinin, en önemli özelliği, tüketim, üretim ve yatırım kararlarının majör belirleyicilerine ilişkin bilgi sağlamasıdır. Bu indikatörler, tüketim, üretim ve yatırım faaliyetlerinin gelecek dönemdeki trendlerine ilişkin sinyaller verdiği için, hanehalkları, işletmeler ve merkez bankalarl gibi çeşitli ekonomik birimler, güven indikatörlerini, tahmin ve karar alma mekanizmalarına dahil etmektedir. Bu çerçevede, hanehalklar ve firmaların ekonomik görünüme ilişkin beklentilerini ölçmek amacıla kullanılan güven endeksleri, makroekonomik indikatörlerdeki değişimleri büyük ölçüde yansitmaktadır. Bu çalışmanın amacı, 2012:052020:09 döneminde, Türkiye için, güven indikatörlerinin trendinin analiz edilmesidir. Analizde, Carrion-i Silvestre ve dĭg. (2009) tarafindan geliştirilen birimkök testi kullanilarak, tüketici, finansal hizmetler ve reel sektör güven endekslerinin dură̆anlı̆̆ı, yapısal kırılmalar dikkate alınarak test edilmektedir. Analiz sonuçları, ilgili dönemde, reel sektör ve finansal hizmetler güven endekslerinin istikrarlı bir trende sahip olduğuna; diğer yandan tüketici güven endeksinin dalgalı bir görünüme sahip olduğuna işaret etmektedir. Analiz aynı zamanda, yapısal kırlma tarihlerini göstermektedir.
\end{abstract}

Anahtar kelimeler $\quad$ : Güven indikatörleri, Belirsizlik, Yapısal kirılmalar.

Jel Sinıflandirması $\quad$ : C10, E70, G40.

\section{INTRODUCTION}

"In highly uncertain environments, many economic decisions are the results of animal spirits, i.e. spontaneous urges to action." indicates Akerlof and Shiller (2009) in their well-known statement. The U.S experienced its most destructive crisis in 2008-09 following the 1929 Great Depression, in which uncertainty and risk premium peaked and the whole world witnesses irrational movements. The 200809 Global Financial Crisis, which occurs not only as a result of increased fragilities in financial markets but also arose from the significant decline of confidence in the players and institutions in the financial system, led to critical changes in terms of the real economy, financial markets, and central banking practices. Given the fact that the financial turbulence led to an exacerbation of the confidence crisis, there have become different approaches, which indicate that the loss of confidence was one of the main reasons for increasing the duration and depth of the financial crisis or it was the result of this great financial crisis, which raised many questions about the functioning of the financial system. With this crisis, we see that the number of studies examining confidence issue and the effects of confidence indicators on variables such as economic growth, employment, investments, foreign exchange rates, and stock market indices have been rapidly increasing although the history of the studies focused on the expectations and sentiments dates back to 1930s (Keynes, 1936; Katona, 1951; Cass \& Shell, 1983; Fair, 1971; Mishkin, 1978; Fuhrer, 1993; Matsusaka \& Sbordone, 1995; Bram \& Ludvigson, 1998).

In the academic literature, there are two major contrasting approaches: the information approach and Keynes' animal spirits approach concerning the confidence concept. The information approach views consumer confidence as a reflection of rational expectations for the future. Hence, according to this approach, confidence indicators might provide information on potential economic developments. In principle, any function given to consumer confidence to justify future spending is logically incompatible with rational economic expectations. This suggests that examples of the predictive power of consumer confidence with frictionless markets have to be found outside of the theoretical rational expectations paradigm. Borrowing restrictions, for instance, may prohibit customers from spending more today in expectation of an increase in income. Animal spirits, on the other hand, are a manifestation on the part 
of households of overly optimistic or pessimistic expectations, so that they want more or less consumption under imperfect information. This approach also assumes that independent changes in beliefs have a causal effect on business cycles (Barsky \& Rims, 2012; Neisingh \& Stokman, 2013).

Considering the importance of confidence in terms of the real economy and financial markets, the deterioration in the indicators pointing to the changes in confidence might bring with its adverse effects on macroeconomic variables such as economic growth, inflation, employment, industrial production index, exchange rates by affecting the consumption, production and investment decisions of economic agents. In the studies emphasizing the role of psychological factors such as expectations and sentiments, it is indicated that the increase in confidence strengthens optimistic expectations for the future and otherwise feeds pessimistic expectations, thereby reshaping the consumption and investment spendings of economic agents. The fact in the heart of this is the situation of certainty or uncertainty caused by the changes in confidence. In an economic environment in which we can see the future more clearly and uncertainty is reduced, it is sensible to shape our economic decisions with a more optimistic mood. On the other hand, our criteria for assessing confidence are qualitative and partially subjective, since we are not able to measure confidence in a concrete way. In this regard, confidence indexes, which are developed to provide more concrete results, are created through surveys trying to evaluate how economic agents react to changes in the economic environment. More general and objective results are attempted to be acquired through confidence surveys trying to capture several assessments of past, present, and future periods. Since the confidence indicators have the power to simply reflect the changes in economic fundamentals, we can say that confidence indicators can be used quite beneficially in economic analysis and prediction of conjunctural economic trends. Hence, this information can provide insight into future economic activity to policymakers and researchers.

In this paper, our focusing point is to analyze the consistency of confidence indexes. After taking a closer look at the determinants and the trend of confidence indexes, we try to test the consistency of consumer, financial services, and real sector confidence indexes in Turkey for the period from 2012:05 through 2020:09 by employing the Carrion-i Silvestre et al. (2009) unit root test. There are a few studies that focus on confidence indexes for emerging market economies. To our knowledge, our study is one of these papers which analyzes the confidence indicators for emerging market economies. Moreover, this recent unit root test proposed by Carrion-i Silvestre et al. (2009) allows for more powerful results when compared to the traditional unit root tests.

The study is organized as follows. In Section 1, we provide brief information about the determinants of confidence indicators in the last period. After introducing the other studies in the academic literature focusing on confidence indicators in Section 3, we attempt to evaluate the consistency of the confidence indexes and report the findings acquired by employing the Carrion-i Silvestre et al. (2009) unit root test. Finally, we conclude by discussing the estimation results and introducing some policy implications.

\section{WHICH FACTORS DO HAVE AN IMPACT ON CONFIDENCE INDICATORS?}

The most important feature of confidence indicators is probably the information they provide about the major determinants of consumption, production, and investment decisions. As they indicate future patterns of consumption, production, and investments, many economic agents including households, businesses, and central banks integrate these indicators into their processes of forecasting and decision-making. Willingness to buy, willingness to produce, and willingness to invest are the sentiments that the confidence indexes seek to capture. Such feelings are, from a theoretical point of view, just about perceptions and uncertainty regarding the economic variables. (Lopez \& Durre, 2003).

What are the main drivers of the confidence indexes? For the consumer confidence index, two of these factors which are in a relationship with spendings are job growth and income growth. In this context, the unemployment rate can not only affect income directly, but it can also have a psychological 
impact. Hearing about people losing their jobs, we probably tend to save more because of concerns about losing our jobs too. Changes in wealth also affect the willingness of economic agents to spend and invest. Inflation is another indicator that can have an impact on expectations. How much businesses spend to expand production capacity depends on many factors. Interest rates, corporate profits, the cost of construction, and new equipment are the factors that do have impacts on the real sector confidence index. Lower interest rates mean that it is easier for the rate of return from the investment to be higher than the cost of paying for the investment. Corporate profits help improve the expectations regarding the business environment and consumer demand is also a very important factor. If businesses observe that consumer demand is increasing, they will have more optimistic expectations (Rogers, 2009).

Monetary or fiscal policy, inflation, purchasing power all affect the confidence indicators. Price stability, financial stability, and political stability are of great importance for confidence. When we take a closer look at the confidence issue in Turkey, we see that the confidence indicators seem a deteriorating trend, particularly in the last a few-year period. In the post-crisis era after 2001, a highly optimistic outlook was of great importance in restoring the Turkish economy. Despite the financial instability in the U.S and Eurozone in the past decade, Turkey's economic success has been driven largely by its sound financial system in that period. So what factors could be responsible for Turkey's low levels of confidence in the recent period?

At first, Turkey has been facing a distressed political landscape during the last five years. We have witnessed several elections, which created uncertainty about the political and economic course of the country. There was indeed a clear wave of optimism in Turkey until 2016. The inflation rate is quite stabilized thanks to the inflation targetting regime which has been implemented since 2006. A stable economic environment attracted foreign investors both in the form of direct investments and portfolio investments. The growth rates were quite high with annual economic growth rates of approximately twelve percent. Under such favorable circumstances, we see that households consumed more, businesses invested, and produced more (Trading Economics, 2019). Unfortunately, the military coup attempted in 2016, the political tension with the U.S in 2018, and elections in the past few-year period notably led to an increase in political risk. There is an obvious relationship between political risk and confidence indicators. This wave of pessimism was followed by the increasing tension with Syria in 2019. In the last period, increasing external debt, rising inflation, and weakening economic growth have contributed to the instability of confidence in recent years. When people lose their trust in the real economy as we witness in the last period, this will have longer-lasting adverse impacts on all confidence indicators, and restoring confidence takes a long time in both the real economy and financial markets. In the first half of 2020, there was a significant decline in the confidence indexes particularly in the real sector and financial services confidence indexes resulting from the COVID-19 pandemic. In this period, in which the many sectors were ccouplosed and the social isolation and remote working were carried out, the consumer confidence index, the financial services confidence index, and the real sector confidence index decreased to 78.18, 137, and 66.8. The values were 80.98, 157.9, and 99.7 in March, respectively (CBRT, 2020). The main reason for this deterioration was the sharp increase in uncertainty regarding macroeconomic performance. Considering that the real sector confidence index is a more critical indicator concerning the economic outlook than the other indexes, the significant decline in this index is understandable.

The consumer confidence index, which signals the future movements of household consumption and savings, is based on the financial expectations relating to the general economic situation, employment, and savings. An index value above 100 thresholds indicates that consumers have increased their confidence in the future economic situation; thus reducing their savings and increasing their consumption in the future. On the other hand, an index value below the threshold of 100 signals pessimistic expectations relating to future economic activity and a decreasing trend of consumption (OECD, 2019). The real sector confidence index, representing the real economy expectations, is based on expectation surveys to measure the changes related to production activities and provides information on future developments. This indicator is used to monitor output growth and estimate economic activity turning points. Similar to the consumer confidence index, any value above 100 threshold points to 
optimistic expectations for the performance of the business world soon, while any value below 100 indicates that the pessimistic atmosphere prevails. The real sector confidence index is a very critical indicator, which points to short-term conditions in the business world intending to meet the need of managers and monetary policymakers for early warning systems that are aimed at predicting financial and economic crises. The real sector confidence index, one of the key indicators used to predict the periods of expansion and contraction in economic activity, is based upon business tendencies and reflects the confidence of the business world (OECD, 2020). Finally, the financial services confidence index is based on the CBRT's Financial Services Survey, which is conducted with financial sector institutions and represents confidence in the financial services (CBRT, 2019). The FSCI is an important benchmark representing financial market trends and developments through tracking past assessments and expectations by managers of financial institutions such as banks, insurance, leasing, and factoring companies.

Graph 1, 2 and, 3 show the trends of consumer confidence index (CCI), financial services confidence index (FSCI), and real sector confidence index (RSCI) in the period of 2012:05-2020:09. According to the graphs, there has been a dramatic decline in CCI in the second half of 2018 while the RSCI and FSCI exhibited a significant decline in the same period and then signals to moderate increase. Most notably, the RSCI and FSCI have a relatively upward trend, the CCI has continued its negative trend during the last year period. Geopolitical risks, adverse global factors, and country-specific factors are major determinants in the deterioration of confidence in the last period. Following the significant deterioration in foreign exchange rates and inflation in 2018, despite the measures taken to stimulate economic activity and the partial improvement in foreign exchange rates and inflation, the expectations tended to be pessimistic and confidence sentiment seemed to continue its weak trend. As seen from the graphs, in the second quarter of 2020, as a result of uncertainty stemming from the COVID-19 pandemic, the FSCI and RSCI decreased dramatically while the CCI seemed not to be affected significantly. The upward trend in unemployment rates, negative attitudes towards the investment environment, and the adverse expectations concerning macroeconomic outlook are the key factors in this negative trend.

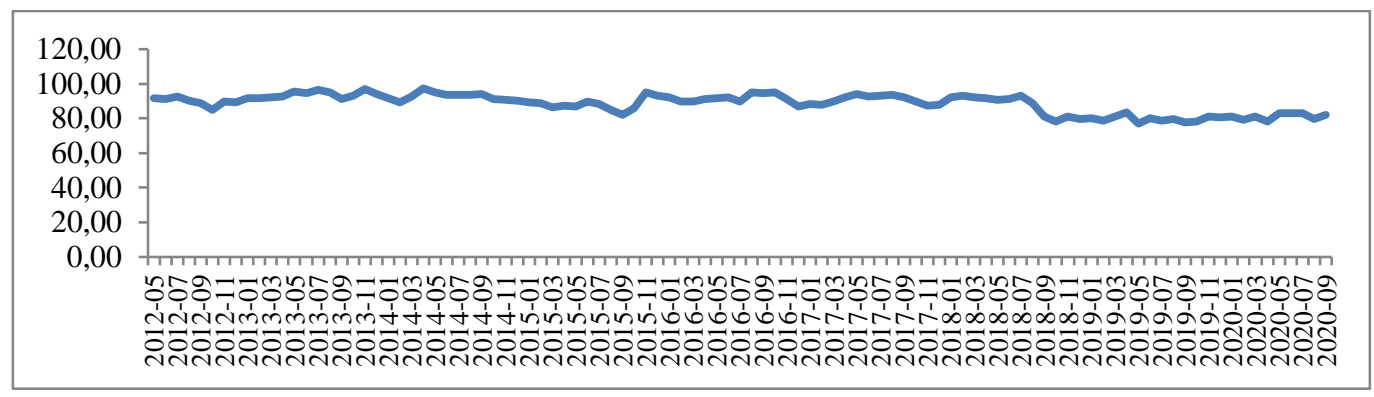

Graph 1. Consumer Confidence Index: 2012:05-2020:09

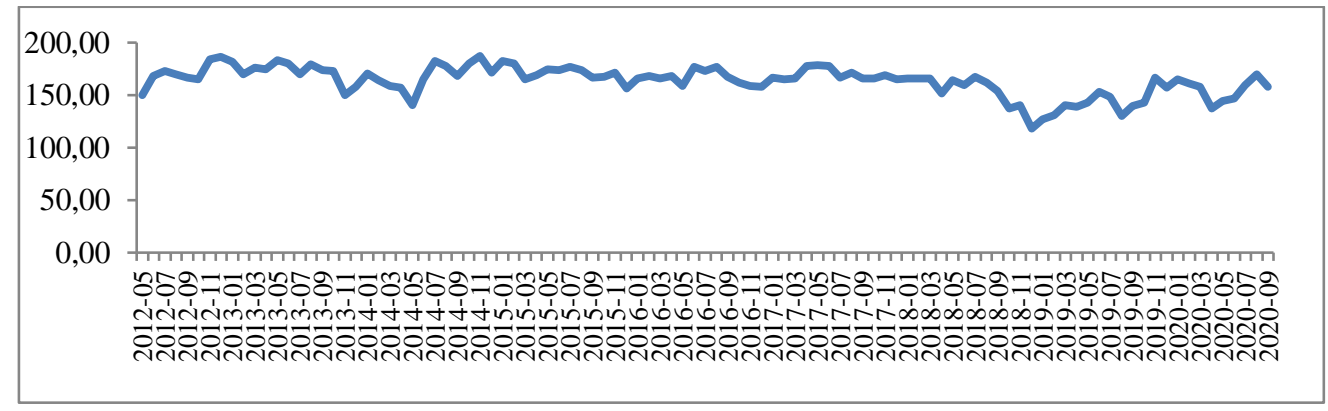

Graph 2. Financial Services Confidence Index: 2012:05-2020:09 


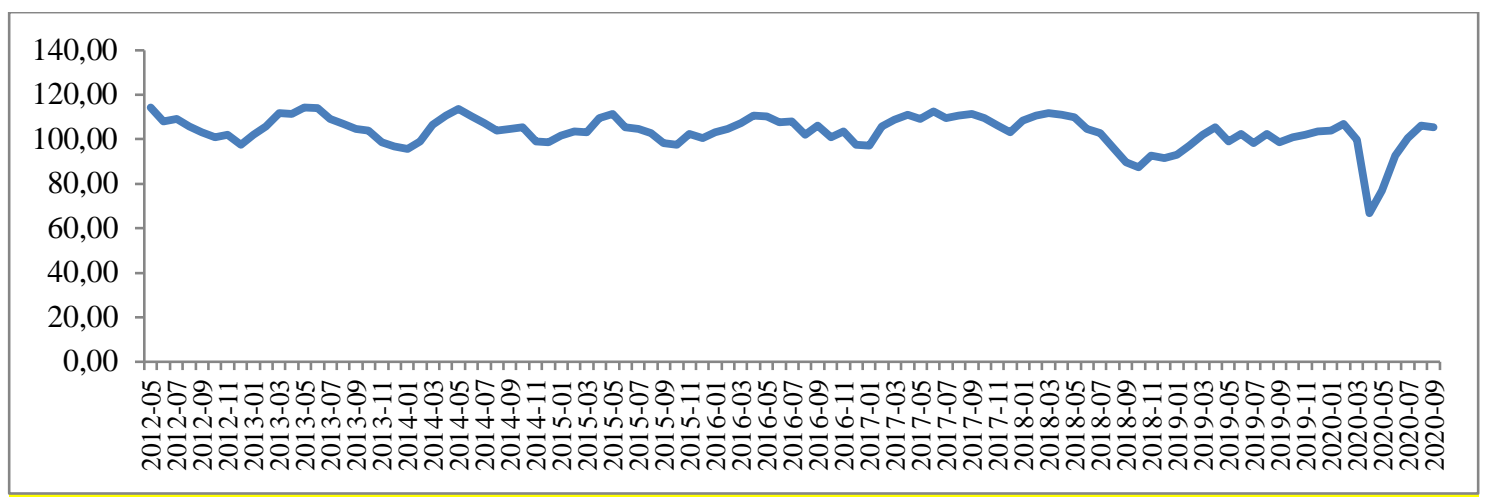

Graph 3. Real Sector Confidence Index: 2012:05-2020:09

Source: Series are obtained from CBRT EVDS.

\section{BRIEF LITERATURE ON CONFIDENCE INDICATORS}

There are several studies in the academic literature on the role of confidence issue in economic analysis. From the empirical viewpoint, the literature mainly investigates whether confidence indicators might contain any information that could be helpful to forecast future changes in macroeconomic variables. Some of these studies examine the predictive power of consumer sentiment for future changes in consumption spending. Many researchers, in particular, emphasize the special significance of confidence indicators in forecasting cycles of strong economic fluctuations. In addition to the role of confidence in consumption behavior, the academic literature is also interested in the role of sentiment in business cycles, as the expectations of economic agents regarding the future impact not only consumption but also investment decisions and production of firms (ECB, 2013).

The University of Michigan's Consumer Sentiment Index and the Conference Board's Consumer Confidence Index are the most commonly pursued measures of U.S consumer confidence (Bram \& Ludvigson, 1998). Huth et al (1994), analyzing both of these indexes to predict product demand and aggregate buyer behavior dynamics, indicate that these indexes are helpful in forecasting potential levels of aggregate consumer spending, business spending, and economic activity. The Michigan index tends to outperform the Conference Board estimate in forecasting durable good purchases, while the opposite is valid for general economic performance, suggesting that both indicators are effective in forecasting economic activity. In a similar study using Michigan's and Conference Board's data, Ludvigson (2004) analyzes consumer confidence and consumer spending relationship and find that the consumer confidence indexes are useful in forecasting future consumption. Confidence indexes can be very beneficial in periods of great economic, financial, or political shocks. These cycles are generally correlated with the high volatility of consumer and real sector confidence, indicating that broad fluctuations in confidence might be valuable indicators of consumption, production, and investment decisions. From this perspectives, Desroches and Gosselin (2002) examine the effectiveness of consumer confidence indexes in estimating aggregate consumer spending in the U.S. Their findings suggest that economists and researchers, particularly in periods of high economic pr political volatility, should pay attention to consumer confidence.

Focusing on Dutch confidence data, Franses and van Ouest (2006) suggest a methodological approach to assess improvements in consumer confidence indicators. Stressing that a new approach is developed because such indicators are evaluated on monthly basis and each cycle includes individual people, so a clear analysis of improvements might be complicated. Their suggested framework includes predicting the transition matrix which links the fractions of positive, neutral, and negative opinions. An 
example of almost two decades of Dutch data indicates that monthly shifts in consumer confidence do not often differ dramatically from zero. Ironically, though, the major values tend to precede cycles of specific downturns and increases in the Dutch economy. In a study focusing on examining whether confidence and business indicators could forecast GDP fluctuations across the business cycles for four European economies, Taylor and Mcnabb (2007) analyze the predictive power of confidence indicators. After examining whether they could estimate specific events, including economic downturns, and whether they might quantitatively project economic activity figures, they notice that both consumer and business confidence indicators are procyclical and typically play a major role in forecasting downturns.

McKecnie and Gritten (2011), trying to examine the degree to which consumer confidence has been tarnished and how post-recession patterns have progressed, aim to explore what has changed in the British psyche following the credit crunch and to hypothesize the degree to which consumer behavior stays stable or tends to shift in the face a possible backdrop of sustained financial stability. Mariana (2012) analyzes the hypothesis that the industrial confidence indicator is influenced by the economic sector reference series presented by the industrial production index and in the same period bears the stamp of certain macroeconomic indicators that belonged to Romania, Euro-Area, and the other countries. In this context, they investigate the relationship between the industrial confidence indicator and macroeconomic indicators. And for the factors described they elaborate models of multivariate classical and discrete regression that illustrate confidence-building in industry. Their results suggest that the industrial confidence indicator of Romania is more heavily affected by the Euro-Area reference series than separately reported series at the national level. In a research focusing on South Africa, Ndou et al. (2017) attempt to determine the role of business confidence in economic growth by employing the counterfactual analysis. They further examine the role of the volatility of exchange rates and the uncertainty of economic policy in the transmission of shocks experienced in negative business confidence into consumer consumption, exports, and GDP growth. They emphasize that business confidence plays a major role in spreading or magnifying the optimistic spillovers of growth from the U.S and China into South African GDP growth. Their findings show that growth in GDP, consumption and, a decline in export seems much more in the absence of exchange rate volatility following a negative shock in business confidence than when the model shuts off volatility. Moreover, evidence suggests that South African GDP growth and consumption spending decline in the face of accelerated uncertainty in economic policy owing to the adverse shocks of business confidence.

Although there are numerous studies in the U.S and Euro-Area, we see that very few studies on the confidence indicators in Turkey. The studies of Ozsagir (2007), Korkmaz and Celik (2009), Eyuboglu and Eyuboglu (2017), and Kilci (2020) could be given as reference papers, which empirically analyze the confidence indicators. Of these, Ozsagir (2007) in his study, find evidence of a strong relationship between RSCI in the period of 1988-2005. The confidence phenomenon is of great importance in terms of stock market indices. In this regard, Korkmaz and Celik (2009) analyze the causality relationship between ISE100 (Istanbul Stock Exchange 100) Index and the real sector confidence index through the EGARCH model. Their findings imply that there is a feedback effect between the ISE 100 index return and confidence index, signaling simultaneous interaction between each other. Stating that future expectations concerning the economy notably affect the stock price changes, Eyuboğlu and Eyuboglu (2017) utilize the economic confidence index (ECI) to test the longrun relationship between the ECI and stock prices for the period of 2012:01-2016:10. Their findings support the evidence of the long-run impact of ECI on stock prices. Analyzing the impact of the financial services and real sector indexes on indicators such as interest rates, inflation, industrial production, foreign exchange rates, and stock market indices for Turkey in the period of 2012:05-2019:05, Kilci (2020) finds a close link between confidence indexes and the macroeconomic and financial variables such as inflation and stock market index, supporting the evidence of the short-run impact of the real sector and financial services confidence indexes on these variables. 


\section{EMPIRICAL ANALYSIS}

In our analysis, we simply search for the answer to that question of whether confidence indicators do have a stable pattern or not for Turkey in the period of 2012:05-2020:09. In this context, we employ the Carrion-i Silvestre et al. (2009) unit root test to examine the stationary of confidence indexes following using the conventional unit root tests. This test accounts for up to five structural breaks for unit root and allows us to place much more confidence in the results. Details of the test and our data are summarized below.

\section{III.I. Data and Methodology}

In Turkey, the CBRT has been periodically conducting surveys in order to provide information regarding the consumer, financial services, and real sector confidence indexes. In our analysis, we use monthly data for the period of 2012:05-2020:09 covering the COVID-19 pandemic. The data source for our variables is the Central Bank of the Republic of Turkey EVDS. Our period beginning from 2012:05 appears limited because we do not have financial services confidence data before that data. Despite this limitation, it seems adequate to conduct our analysis. Table 1 presents our variables, their frequencies, and the sources which we acquire from.

Table 1. List of Variables

\begin{tabular}{llcr}
\hline $\begin{array}{l}\text { Independent } \\
\text { Variables }\end{array}$ & Measure & Abbreviation & Source \\
\hline Confidence Indicator 1 & Consumer Confidence Index & CCI & CBRT \\
Confidence Indicator 2 & Financial Services Confidence Index & FSCI & CBRT \\
Confidence Indicator 3 & Real Sector Confidence Index & RSCI & CBRT \\
\hline
\end{tabular}

Note: Variables appear monthly in our analysis.

The unit root test proposed by Carrion-i Silvestre et al. (2009) proposed a unit root test which allows for up to five structural breaks. The data generating process (DGP) of the test can be written as below:

$y_{t}=d_{t}+u_{t}$
$u_{t}=\alpha u_{t-1}+v_{t}, \quad t=0,1, \ldots T$

where ${ }^{u_{t}}$ denotes an unobserved mean-zero process. They use five different statistics in testing the null hypothesis of unit root under multiple structural breaks. The feasible point optimal statistic, one of these statistics, is written as follows:

$P_{T}^{G L S}\left(\lambda^{0}\right)=\frac{\left\{S\left(\bar{\alpha}, \lambda^{0}\right)-\bar{\alpha} S\left(1, \lambda^{0}\right)\right\}}{s^{2}\left(\lambda^{0}\right)}$

Here, $\lambda$ is the break fraction, $\bar{\alpha}$ equals to $1+\bar{c} / T$ with the $\bar{c}$ is the noncentrality parameter and $s^{2}\left(\lambda^{0}\right)$ is an estimate of the spectral density at frequency zero of ${ }^{v_{t}}$. Moreover, Carrion-i Silvestre et 
al. (2009) utilize the M-class of tests examined in Ng and Perron (2001) allowing for multiple structural breaks as follows:

$$
\begin{aligned}
& M Z_{\alpha}^{G L S}\left(\lambda^{0}\right)=\left(T^{-1} \tilde{y}_{T}^{2}-s\left(\lambda^{0}\right)^{2}\right)\left(2 T^{-2} \sum_{t=1}^{T} \tilde{y}_{t-1}^{2}\right)^{-1} \\
& M S B_{T}^{G L S}\left(\lambda^{0}\right)=\left(s\left(\lambda^{0}\right)^{-2} T^{-2} \sum_{t=1}^{T} \tilde{y}_{t-1}^{2}\right)^{\frac{1}{2}} \\
& M Z_{T}^{G L S}\left(\lambda^{0}\right)=\left(T^{-1} \tilde{y}_{T}^{2}-s\left(\lambda^{0}\right)^{2}\right)\left(4 s\left(\lambda^{0}\right)^{2} T^{-2} \sum_{t=1}^{T} \tilde{y}_{t-1}^{2}\right)^{\frac{-1}{2}}
\end{aligned}
$$

with $\tilde{y}_{t}^{2}=y_{t}-\hat{\psi}^{\prime} z_{t}\left(\lambda^{0}\right)$ where $\hat{\psi}$ minimizes the objective function and $s\left(\lambda^{0}\right)^{2}$ denotes autoregressive estimation function. The modified feasible point optimal test statistic, which Carrion-i Silvestre et al. (2009) use as a last istatistic, following Ng and Perron (2001), is stated as:

$$
M P_{T}^{G L S}\left(\lambda^{0}\right)=\frac{\left[\bar{c}^{2} T^{-2} \sum_{t=1}^{T} \tilde{y}_{t-1}^{2}+(1-\bar{c}) T^{-1} \tilde{y}_{T}^{2}\right]}{s\left(\lambda^{0}\right)^{2}}
$$

As its limiting distribution coincides with the feasible point optimal test, the $M P_{T}^{G L S}\left(\lambda^{0}\right)$ has an importance. Carrion-i Silvestre et al. (2009) acquire the asymtotic critical values of the unit root test through bootstrap approach. If the corresponding critical values are bigger than the calculated test statistics, the null hypothesis can be rejected, implying the absence of a unit root.

\section{III.II. Empirical Results}

In the first step, we employ traditional ADF and PP unit root tests with intercept and trend and neglect the possible structural breaks. Table 2 presents the findings.

Table 2. The Results of ADF and PP Unit Root Tests

\begin{tabular}{lllll}
\hline \hline & ADF & & PP & \\
\hline \hline Series & Level & First difference & Level & First difference \\
\hline CCI & -3.385 & $-8.610^{*}$ & -3.218 & $-21.818^{*}$ \\
FSCI & $-5.005^{*}$ & $-12.123^{*}$ & $-5.038^{*}$ & $-16.470^{*}$ \\
RSCI & $-5.084^{*}$ & $-10.235^{*}$ & $-3.906^{*}$ & $-8.931^{*}$ \\
\hline \hline
\end{tabular}

$*$ indicates rejection of the unit root null hypothesis at the $5 \%$ significance level.

The findings of the ADF and PP unit root tests indicate that the CCI series have a unit root in level but stationary after first differencing while the FSCI and RSCI series are stationary in level. As Perron (1989) stresses that neglecting a structural break could result in misappropriation of the unit root null hypothesis, we expand our unit root analysis with structural breaks by applying the Carrion-i Silvestre et al. (2009) unit root test. The benefit of this unit root test is that it allows for up to five structural breaks. Since it is possible to take into account one, two, and three structural breaks in our analysis depending on the length of our data period, we employ Carrion-i Silvestre et al. (2009) unit root test by taking into consideration structural breaks up to three in level and trend. Table 3 presents the findings. 
Kılcı, E. N. (2021). A study on confidence indexes in Turkey under structural breaks for the period covering the Covid-19 pandemic. Ömer Halisdemir Üniversitesi İktisadi ve İdari Bilimler Fakültesi Dergisi, 14(3), 948-960.

Table 3. The Results of Carrion-I Silvestre et al. (2009) Unit Root Test

\begin{tabular}{|c|c|c|c|c|c|c|}
\hline \multirow[b]{2}{*}{ Series } & \multicolumn{5}{|c|}{ Panel A: The results for one break } & \multirow[b]{2}{*}{ Break years } \\
\hline & $P_{T}$ & $M P_{T}$ & $M Z_{\alpha}$ & $M S B_{T}$ & $M Z_{T}$ & \\
\hline $\mathrm{CCI}$ & $\begin{array}{l}8.031 \\
{[6.965]}\end{array}$ & $\begin{array}{c}7.934 \\
{[6.965]}\end{array}$ & $\begin{array}{c}-21.274 \\
{[-23.925]}\end{array}$ & $\begin{array}{c}0.151 \\
{[0.143]}\end{array}$ & $\begin{array}{c}-3.232 \\
{[-3.441]}\end{array}$ & 2015:10 \\
\hline FSCI & $\begin{array}{l}5.977 \\
{[6.672]}\end{array}$ & $\begin{array}{c}5.728 \\
{[6.672]}\end{array}$ & $\begin{array}{c}-26.397 \\
{[-23.011]}\end{array}$ & $\begin{array}{c}0.137 \\
{[0.145]}\end{array}$ & $\begin{array}{c}-3.625 \\
{[-3.372]}\end{array}$ & 2013:10 \\
\hline \multirow[t]{2}{*}{$\mathrm{RSCI}$} & $\begin{array}{c}1.895 \\
{[5.915]}\end{array}$ & $\begin{array}{l}1.764 \\
{[5.915]}\end{array}$ & $\begin{array}{c}-59.423 \\
{[-17.953]}\end{array}$ & $\begin{array}{c}0.091 \\
{[0.164]}\end{array}$ & $\begin{array}{c}-5.449 \\
{[-3.011]}\end{array}$ & 2020:03 \\
\hline & \multicolumn{5}{|c|}{ Panel B: The results for two breaks } & \\
\hline $\mathrm{CCI}$ & $\begin{array}{l}8.451 \\
{[7.602]}\end{array}$ & $\begin{array}{l}8.098 \\
{[7.602]}\end{array}$ & $\begin{array}{c}-27.478 \\
{[-29.162]}\end{array}$ & $\begin{array}{c}0.134 \\
{[0.130]}\end{array}$ & $\begin{array}{c}-3.703 \\
{[-3.805]}\end{array}$ & 2015:10; 2018:08 \\
\hline FSCI & $\begin{array}{c}6.755 \\
{[7.332]}\end{array}$ & $\begin{array}{l}6.338 \\
{[7.332]}\end{array}$ & $\begin{array}{c}-33.181 \\
{[-28.702]}\end{array}$ & $\begin{array}{c}0.122 \\
{[0.131]}\end{array}$ & $\begin{array}{c}-4.070 \\
{[-3.778]}\end{array}$ & $2013: 10 ; 2018: 11$ \\
\hline \multirow[t]{2}{*}{$\mathrm{RSCI}$} & $\begin{array}{l}2.006 \\
{[5.925]}\end{array}$ & $\begin{array}{l}1.8765 \\
{[5.925]}\end{array}$ & $\begin{array}{c}-55.922 \\
{[-18.108]}\end{array}$ & $\begin{array}{c}0.094 \\
{[0.162]}\end{array}$ & $\begin{array}{c}-5.287 \\
{[-3.045]}\end{array}$ & $2020: 03 ; 2020: 06$ \\
\hline & \multicolumn{5}{|c|}{ Panel C: The results for three breaks } & \\
\hline $\mathrm{CCI}$ & $\begin{array}{c}5.707 \\
{[6.102]}\end{array}$ & $\begin{array}{l}5.601 \\
{[6.102]}\end{array}$ & $\begin{array}{c}-38.360 \\
{[-33.558]}\end{array}$ & $\begin{array}{c}0.114 \\
{[0.123]}\end{array}$ & $\begin{array}{c}-4.373 \\
{[-4.089]}\end{array}$ & 2014:03; 2015:10; 2018:08 \\
\hline FSCI & $\begin{array}{c}4.348 \\
{[5.594]}\end{array}$ & $\begin{array}{c}4.205 \\
{[5.594]}\end{array}$ & $\begin{array}{c}-41.309 \\
{[-29.577]}\end{array}$ & $\begin{array}{c}0.109 \\
{[0.133]}\end{array}$ & $\begin{array}{c}-4.539 \\
{[-3.828]}\end{array}$ & 2012: 10; 2013:10; 2018:11 \\
\hline $\mathrm{RSCI}$ & $\begin{array}{c}2.389 \\
{[6.795]} \\
\end{array}$ & $\begin{array}{c}2.270 \\
{[6.795]}\end{array}$ & $\begin{array}{c}-76.499 \\
{[-26.202]} \\
\end{array}$ & $\begin{array}{c}0.080 \\
{[0.137]}\end{array}$ & $\begin{array}{c}-6.184 \\
{[-3.623]} \\
\end{array}$ & $2017: 01 ; 2020: 03 ; 2020: 06$ \\
\hline
\end{tabular}

Note: Numbers in square brackets are critical values acquired from bootstrap approach for 5 percent significance level.

The findings in Table 3 show that the corresponding critical values are smaller than the calculated test statistics for two cases with one and two structural breaks, meaning that the unit root null hypothesis can not be rejected for the CCI series and the CCI series has a unit root. When we analyze the results for the FSCI and RSCI series, as we see that the critical values are bigger than all the calculated test statistics for all cases with one, two, and three structural breaks, we can reject the unit root null hypothesis for the FSCI and RSCI implying that these two series do not have a unit root. To summarize, the FSCI and RSCI series are stationary in levels for all structural breaks and the CPI series seems stationary for the case with three structural breaks. These results are in line with the findings of the traditional ADF and PP unit root tests. When we analyze the acquired structural breaks, we notice that structural breaks of CCI occur in 2015:10 for one break, in 2015:10 and 2018:08 for two breaks, and in 2014:03, 2015:10 and 2018:08 for three breaks. For FSCI, structural breaks are obtained in 2013:10 for one break, in 2013:10 and 2018:11 for two breaks, and in 2012:10, 2013:10 and 2018:11 for three breaks cases. The structural breaks for RSCI occur in 2020:03 for one break, in 2020:03 and 2020:06 for two breaks, and in 2017:01, 2020:03 and 2020:06 for three breaks. These structural break dates are in line with the expectations regarding the economic outlook in 2018 and 2020, supporting the predictive power of the indexes. Given the fact that the real sector confidence index is the most critical indicator related to the macroeconomic performance, the structural breaks particularly in 2020:03 and 2020:06 signal significant changes in expectations resulting from the COVID-19 pandemic.

\section{CONCLUSION AND POLICY IMPLICATIONS}

The confidence indexes, which are calculated from the survey data related to the past, current, and future economic and financial situations, basically measure the mood of consumers and businesses. These indexes are generally based on the opinions of participants on different issues based on their concerns about current and/or future situations. These indexes are also closely related to issues such as expenditures, investments, and employment. Several studies in academic literature indicate that confidence indexes provide information that acts as a mood signal for assessing the changes in economic activity. The creation of an environment of confidence has critical importance to stimulate consumption and investments in the economy. This paper attempts to analyze the trend of confidence indicators including consumer, financial services, and real sector confidence indexes for the period of 2012:05- 
2020:09. In answering whether the confidence indicators do have a consistent pattern or not in that period, we employ we employ the unit root test proposed by Carrion-i Silvestre et al. (2009). This new unit root test permits us to take into account multiple structural breaks. As the literature on the confidence indicators is limited in Turkey, our study is expected to be pretty useful by also applying a recent approach in the analysis. Our findings indicate that while the RSCI and FSCI seem to have a consistent pattern, the CCI tends to be unstable in the relevant period. Besides, our results are in line with the findings of Taylor and Mcnabb (2007), McKecnie and Gritten (2011), and Mariana (2012).

Graph 1, 2, and 3 show the dramatic decline in consumer, financial services, and real sector confidence indexes in the third quarter of 2018 and the second half of 2020, respectively. While the rising external debt, the appreciation in the foreign exchange rates against the Turkish lira, and increasing inflation are the important factors that led to a deteriorating economic outlook in 2018, the uncertainty and deterioration in macroeconomic outlook resulting from the COVID-19 pandemic led to a decrease in the confidence indexes in 2020. Besides, Turkey has been faced with severe financial turbulence due to capital outflows from emerging market economies and severe uncertainty resulting from both global and country-specific factors. As a result of both the exchange rate and interest rate shocks, increasing uncertainty has led to liquidity crunch and difficulties in access to financial sources. Considering the impacts of the deterioration in macroeconomic outlook as well as the pessimism in economic expectations on the confidence indicators, the steps relating to reestablishing the confidence such as eliminating the uncertainty in economic policies, strengthening structural reforms, improving macroeconomic fundamentals such as inflation, employment, and debt sustainability as well as increasing transparency do have critical importance in the future.

\section{REFERENCES}

Akerlof, G. A., \& Shiller, R. J. (2009). Animal spirits: How human psychology drives the economy and why it matters for global capitalism. New Jersey: Princeton University Press.

Barsky, R. B. \& Sims, E. R. (2012). Information, animal spirits, and the meaning of innovations in consumer confidence. The American Economic Review, 102(4), 1343-1377. https://doi.org/10.1257/aer.102.4.1343.

Bram, J. \& Ludvigson, S. C. (1998). Does consumer confidence forecast household expenditure? A sentiment index horse race. Economic Policy Review, 4(2), 59-78. Retrieved from https://www.newyorkfed.org/research/epr/98v04n2/9806bram.html.

Carrion-i Silvestre, J.L., Kim, D. \& Perron, P. (2009). GLS based unit root tests with multiple structural breaks under both the null and the alternative hypotheses. Econometric Theory, 25(6), 1754-1792. https://doi.org/10.1017/S0266466609990326.

Cass, D. \& Shell, K. (1983). Do sunspots matter?. Journal of Political Economy, 91(2), 193-227. Retrieved from https://www.journals.uchicago.edu/doi/pdf/10.1086/261139.

Central Bank of the Republic of Turkey (2020). Electronic data delivery system (EVDS). Retrieved from https://evds2.tcmb.gov.tr/index.php?/evds/serieMarket.

Central Bank of the Republic of Turkey (2019). Financial services statistics and financial services confidence index. Retrieved from https://www.tcmb.gov.tr/wps/wcm/connect/9d2d0544-b3bd-4641-aed9cf82621a905b/FSS-Report-Int.pdf?MOD=AJPERES\&CACHEID=ROOTWORKSPACE-9d2d0544b3bd-4641-aed9-cf82621a905b-mCBazHv.

Desroches, B. \& Gosselin, M. A. (2002). The usefulness of consumer confidence indexes in the United States. Bank of Canada Staff Working Paper 2002-22. Retrieved from https://www.bankofcanada.ca/wpcontent/uploads/2010/02/wp02-22.pdf.

Dickey, D. \& Fuller, W. (1979). Distribution of the estimators for autoregressive time series with a unit root. Journal of the American Statistical Association, 74, 427-431. https://doi.org/10.2307/2286348.

European Central Bank (2013), Monthly bulletin. Retrieved from https://www.ecb.europa.eu/pub/pdf/other/art1_mb201301en_pp45-58en.pdf.

Eyuboglu, K. \& Eyuboglu, S. (2017). Ekonomik güven endeksi ile hisse senedi fiyatları arasındaki ilişkinin incelenmesi: Türkiye örneği Gazi Üniversitesi İktisadi ve İdari Bilimler Fakültesi Dergisi, 19(2), 603 614. Erişim adresi: https://dergipark.org.tr/tr/download/article-file/459325. 
Kılcı, E. N. (2021). A study on confidence indexes in Turkey under structural breaks for the period covering the Covid-19 pandemic. Ömer Halisdemir Üniversitesi İktisadi ve İdari Bilimler Fakültesi Dergisi, 14(3), 948-960.

Fair, R. C. (1971). Consumer sentiment, the stock market and consumption functions. Princeton University Econometric Research Program Research Memorandum, No: 119. Retrieved from https://www.princeton.edu/ erp/ERParchives/archivepdfs/M119.pdf.

Franses, Ph.H.B.F, \& Van Oest, R.D. (2006). Testing changes in consumer confidence indicator. Econometric Institute Report 2006-18. Retrieved from http://hdl.handle.net/1765/7675.

Fuhrer, J. C. (1993). What role does consumer sentiment play in the U.S. economy? Federal Reserve Bank of Boston. New England Economic Review, 32-44. Retrieved from https://www.bostonfed.org//media/Documents/neer/neer193b.pdf.

Huth, W. L., Eppright, D. R., \& Taube, P. M. (1994). The indexes of consumer sentiment and confidence: Leading or misleading guides to future buyer behavior. Journal of Business Research, 29(3), 199-206. https://doi.org/10.1016/0148-2963(94)90004-3.

Katona, G. (1951). Psychological analysis of economic behavior. New York: McGraw-Hill Press.

Keynes, J. M. (1936). The general theory of interest, employment and Money. Macmillan Cambridge University Press.

Kilci, E. N. (2020). Do confidence indicators have an impact on macro-financial indicators? An analysis of the financial services and real sector confidence indexes: Evidence from Turkey. European Journal of Government and Economics, 9(1), 74-94. https://doi.org/10.17979/ejge.2020.9.1.5948.

Korkmaz, T. \& Çevik, E. İ. (2009). Reel kesim güven endeksi ile İMKB 100 Endeksi arasındaki dinamik nedensellik ilişkisi. İstanbul Üniversitesi İşletme Fakültesi Dergisi, 38(1), 24-37. Erişim adresi: https://dergipark.org.tr/tr/download/article-file/98145.

Lopez, H. B., \& Durre, A. (2003). The determinants of consumer confidence: the case of United States and Belgium. CORE Discussion Papers, 2003053, Université Catholique de Louvain, Center for Operations Research and Econometrics. from https://citeseerx.ist.psu.edu/viewdoc/download?doi=10.1.1.196.8667\&rep=rep1\&type=pdf.

Ludvigson S. C (2004). Consumer confidence and consumer spending. Journal of Economic Perspectives, 18(2), 29-50. https://doi.org/10.1257/0895330041371222.

Mariana, G. (2012). Confidence indicators analysis in the context of Romanian and European Economy. Procedia - Social and Behavioral Sciences, 62, 393-397. https://doi.org/10.1016/j.sbspro.2012.09.063.

Matsusaka, J. G. \& Sbordone, A. M. (1995). Consumer confidence and economic fluctuations. Economic Inquiry, 33(2), 296-318. https://doi.org/10.1111/j.1465-7295.1995.tb01864.x.

McKecnie, S. \& Gritten, A. (2011). New insights into consumer confidence in financial services. International Journal of Bank Marketing, 29(2), 90-106. https://doi.org/10.1108/02652321111107602.

Mishkin, F. S. (1978). Consumer sentiment and spending on durable hoods. Brooking Papers on Economic Activity, 1, 217-32. https://doi.org/10.2307/2534366.

Ndou, E., Gumata N. \& Ncube, M. (2017). Business confidence shocks and the relevance of exchange rate volatility and economic policy uncertainty channels. Ndou, E., Gumato, N., \& Ncube, M. (eds.), In Global Economic Uncertainties and Exchange Rate Shocks (383-399). London: Palgrave Macmillan,

Neisingh, P. \& Stokman, Ad. C.J. (2013). What drives consumer confidence in times of financial crises? Evidence for the Netherlands. De Nederlandsche Bank Working Paper, No: 394. Retrieved from https://www.dnb.nl/media/r05fyrkp/working-paper-394.pdf.

Ng, S. \& Perron, P. (2001). Lag length selection and the construction of unit root tests with good size and power, Econometrica, 69, 1519-1554. Retrieved from http://www.jstor.org/stable/2692266?origin=JSTOR-pdf.

Perron, P. (1989). The great crash, the oil price shock and the unit root hypothesis, Econometrica, 57, 1361-1401. https://doi.org/10.2307/1913712.

Phillips, P.C.B. \& Perron, P. (1988). Testing for a unit root in time series regression. Biometrika, 75, $335-346$. https://doi.org/10.2307/2336182.

Rogers, R. M. (2009). The complete idiot's guide to economic indicators: Manage your investments with an eye on the key factors affecting today's market. London: Alpha Books.

OECD (2020), Business Confidence Index (BCI) (indicator). https://doi.org/10.1787/3092dc4f-en.

OECD (2019), Consumer Confidence Index (CCI) (indicator). https://10.1787/46434d78-en.

Ozsagir, A. (2007). Ekonomide güven faktörü. Elektronik Sosyal Bilimler Dergisi, 6(20), 46-62. Erişim adresi: https://dergipark.org.tr/tr/download/article-file/69950.

Taylor, K. \& Macnabb, R. (2007). Business cycles and the role of confidence: Evidence for Europe. Oxford Bulletin of Economics and Statistics, 69(2), 185-208. https://doi.org/10.1111/j.1468-0084.2007.00472.x.

Trading Economics (2019). Turkey-Economic indicators. Retrieved from https://tradingeconomics.com/turkey/indicators. 
Kılcı, E. N. (2021). A study on confidence indexes in Turkey under structural breaks for the period covering the Covid-19 pandemic. Ömer Halisdemir Üniversitesi İktisadi ve İdari Bilimler Fakültesi Dergisi, 14(3), 948-960.

Etik Beyanı

: Bu çalışmanın tüm hazırlanma süreçlerinde etik kurallara uyulduğunu yazarlar beyan eder. Aksi bir durumun tespiti halinde ÖHÜIİB Dergisinin hiçbir sorumluluğu olmayıp, tüm sorumluluk çalışmanın yazar(lar)ına aittir.Çalışma, Etik Beyan raporu gerektirmemektedir.

Yazar Katkıları : Çalışmanın yazarı, makaleye \%100 katkı sağlamıştır.

Çıkar Beyanı : : Çalışmada herhangi bir çıkar çatışması yoktur.

Teşekkür : : Yayın sürecinde katkısı olan hakem ve editörlere teşekkür ederim.

Ethics Statement $\quad$ : The authors declare that ethical rules are followed in all preparation processes of this study. In case of detection of a contrary situation, ÖHÜIIBBF Journal does not have any responsibility and all responsibility belongs to the author $(s)$ of the study. The study does not require a Statement of Ethics report.

Author Contributions : The author of the study contributed $100 \%$ to the article.

Conflict of Interest $\quad$ : There is no conflict of interest in the study.

Acknowledgement : I would like to thank the referees and editors who contributed to the publication process. 